\title{
IN VIVO MICROBIOLOGICAL EVALUATION OF THE EFFECT OF BIOMECHANICAL PREPARATION OF ROOT CANALS USING DIFFERENT IRRIGATING SOLUTIONS
}

\author{
AVALIAÇÃO MICROBIOLÓGICA IN VIVO DO EFEITO DO PREPARO BIOMECÂNICO DOS \\ CANAIS RADICULARES UTILIZANDO DIFERENTES SOLUÇÕES IRRIGADORAS
}

\begin{abstract}
Mário TANOMARU FILHO ${ }^{1}$, José Carlos YAMASHITA², Mario Roberto LEONARDO ${ }^{3}$, Léa Assed Bezerra da SILVA ${ }^{4}$, Juliane Maria Guerreiro TANOMARU², Izabel Yoko ITO ${ }^{5}$
\end{abstract}

\begin{abstract}
1- PhD, Associate Professor, Department of Endodontics, Araraquara Dental School, University of the State of São Paulo, UNESP, Araraquara, SP, Brazil.

2-MSc, PhD in Endodontics, Araraquara Dental School, University of the State of São Paulo, UNESP, Araraquara, SP, Brazil.

3-PhD, Full Professor of Endodontics, Araraquara Dental School, University of the State of São Paulo, UNESP, Araraquara, SP, Brazil.

4-PhD, Full Professor of Pediatric Dentistry, Ribeirão Preto Dental School, University of São Paulo, USP, Ribeirão Preto, SP, Brazil.

5-PhD, Full Professor of Microbiology, Ribeirão Preto Pharmaceutics School, University of São Paulo, USP, Ribeirão Preto, SP, Brazil.
\end{abstract}

Corresponding address: Dr. Mário Tanomaru Filho, Department of Endodontics, Faculdade de Odontologia de Araraquara, UNESP, Rua Humaitá, 1680, Cep.: 14801-903 Araraquara, SP, Brasil. (Business telephone number: +55-16-3301-6390; Home: +55-16-3336-4658; Fax: +55-16-3301-6392). e-mail: tanomaru@uol.com.br

Received: May 05, 2005 - Modification: September 15, 2005 - Accepted: December 22, 2005

\begin{abstract}
$T$

he aim of this study was to evaluate the antimicrobial effect of biomechanical preparation using different irrigating solutions. Seventyeight root canals from premolars of four dogs were used. After experimental induction of periapical lesions, the root canals were prepared using the following solutions for irrigation: Group 1) 2.5\% sodium hypochlorite (NaOCl); Group 2) 2\% chlorhexidine (CHX); Group 3) saline solution and Group 4) control group with no biomechanical preparation. The microbiological evaluation of the root canals was performed by counting the colony forming units (CFUs) using different culture mediums. Two absorbent paper cones were used in each root canal in order to collect the microbiological samples before, and thirty days after the biomechanical preparation. The culture plates were incubated in aerobic, anaerobic and microaerophilic environment. Statistical evaluation was carried out using analysis of variance, Tukey and Student tests. The results demonstrated that there was reduction in the number of microorganisms in the $\mathrm{NaOCl}$ and $\mathrm{CHX}$ groups ( $<<0.05$ ). There was greater effectiveness in the chlorhexidine group. The group that used saline solution and the control group presented an increased number of microorganisms. It can be concluded that the use of antimicrobial irrigating solutions during biomechanical preparation promotes the reduction of endodontic microbiota. However, a considerable number of microorganisms were still observed.

Uniterms: Endodontics; Microbiology; Sodium hypochlorite; Chlorhexidine.
\end{abstract}

\section{RESUMO}

$O$

objetivo deste estudo foi avaliar o efeito antimicrobiano do preparo biomecânico com diferentes soluções irrigadoras. Foram utilizados 78 canais radiculares de pré-molares de 4 cães. Após indução experimental das lesões periapicais, os canais radiculares foram preparados utilizando as seguintes soluções irrigadoras: grupo 1) hipoclorito de sódio a 2,5\% (NaOCl); grupo 2) clorexidina a 2\% (CHX); grupo 3 ) soro fisiológico. No grupo 4 (controle) não foi realizado preparo biomecânico. A avaliação microbiológica do canal radicular foi realizada pela contagem de unidades formadoras de colônia, em ufc, nos diferentes meios de cultura. Foram utilizados 2 cones de papel absorvente em cada canal radicular para a realização da colheita microbiológica antes e 30 dias após o preparo biomecânico. As placas de cultura foram incubadas em ambiente de aerobiose, anaerobiose e microaerofilia. A avaliação estatística foi realizada pela análise de variância complementada pelo teste de Tukey e de Student. Os resultados demonstraram que houve redução dos microrganismos nos grupos $\mathrm{NaOCl}$ e $\mathrm{CHX}(\mathrm{p}<0,05)$, com maior efetividade para a solução de clorexidina. Os grupos que utilizaram solução fisiológica e controle apresentaram aumento do número de microrganismos. Concluiu-se que o emprego de soluções irrigadoras antimicrobianas durante o preparo biomecânico promove a redução da microbiota endodôntica. No entanto foi ainda possível observar um considerável número de microrganismos.

Unitermos: Endodontia; Microbiologia; Hipoclorito de sódio; Clorexidina . 


\section{INTRODUCTION}

The elimination of bacteria present in the root canal system is the fundamental objective of endodontic treatment as they play an important role in the development and maintenance of periapical lesions ${ }^{11,21}$. The high percentages of failure after endodontic treatment of teeth with periapical lesions ${ }^{9,11,12,17,21,23}$ have been related to implications of microbial origin.

Among the phases of endodontic treatment, the biomechanical preparation aims at removal of organic and inorganic debris and modeling of the root canal ${ }^{7}$. During the biomechanical preparation, the chemical action of irrigating solutions plays an important role $e^{3,14,25}$.

Sodium hypochlorite solution has been largely used in endodontic treatment of teeth with necrotic pulp and periapical lesions ${ }^{18}$. The antimicrobial activity, capacity to dissolve organic tissue, low surface tension and detergent action $^{5}$ are important properties attributed to sodium hypochlorite solution.

The residual effect of chlorhexidine solution after usage as an endodontic irrigating solution ${ }^{10,15}$ plays an important role in the disinfection of the root canal system. However, its effectiveness in regions not reached by biomechanical preparation is not known.

The aim of this study was to evaluate, in vivo, the microbiological conditions of root canals of teeth with chronic periapical lesions after biomechanical preparation using different endodontic irrigants.

\section{MATERIALAND METHODS}

Four mongrel dogs were utilized. They aged approximately one year old. The research project was approved by the Ethics Committee in Animal Experimentation of Araraquara Dental School.

The teeth selected for the study were the second, third and fourth mandibular premolars and the second and third maxillary premolars, adding up to seventy-eight root canals.

After the premolar coronal cavities were opened, the exploration of the root canals was done with \#25 K-file (Dentsply Maillefer, Swiss) at 1.5 to $2 \mathrm{~mm}$ from the radiographic apex. With the K-file positioned at this point, radiographs were taken for determination of the total root canal length. The working length was established approximately $2 \mathrm{~mm}$ short of this measurement. Following this, the apical foramen was perforated by using \#20 to \# 30 $\mathrm{K}$-files at the total root length. The root canals remained exposed to the oral environment for seven days, with the objective of permitting their contamination. After this period, the irrigation/aspiration of the pulp chamber was carried out with saline solution, and crown opening was sealed with zinc oxide/eugenol cement (Pulposan S.S.White Artigos Dentários Ltda., Rio de Janeiro, Brazil). After sixty days, radiographic controls were taken to verify the radiolucent images indicating the presence of chronic periapical lesion, according to the method proposed by Leonardo, et al. ${ }^{8}$ (1994).

After experimental induction of periapical lesions, the root canals were prepared using the following solutions for irrigation: Group 1) 2.5\% sodium hypochlorite ( $\mathrm{NaOCl}$ ); Group 2) 2\% chlorhexidine (CHX); Group 3) saline solution and Group 4) control group with no biomechanical preparation (Table 1). After radiographic detection of the periapical lesions, isolation of teeth in one quadrant was carried out using rubber dam and antisepsis of operating field was done using $2 \%$ chlorhexidine digluconate solution. Following this, after removal of coronal sealing, material was collected from the root canals for microbiological evaluation before biomechanical preparation. The root canal was filled with saline solution and the material was collected with two absorbent paper points, placed in sequence and maintained in the root canal for one minute. Then the absorbent paper points were placed into test tubes containing Reduced Transport Fluid (RTF).

The biomechanical preparation was carried out using Kfiles up to \#60 or 70 at the working length. During the whole time of biomechanical preparation, the root canals were irrigated with one of the irrigating solutions tested. The amount of $2 \mathrm{~mL}$ of solution was used at each file change. Then, the root canals were dried and filled with EDTA solution (EDTA, Biodinâmica Química e Farmacêutica Ltda., PR, Brazil), followed by irrigation with saline solution and drying with absorbent paper points (Tanariman Ind. Ltda., Manacapuru, AM, Brazil).

After biomechanical preparation, the crown openings were restored with silver amalgam (Velvalloy, S.S.White Ltda., Rio de Janeiro, Brazil), which was condensed on a glass ionomer base (Vitremer, 3M, St Paul, MN, USA) made at the pulp chamber.

Once the 30-day experimental period had elapsed, after

TABLE 1- Distribution of the experimental groups according to the irrigating solution employed

\footnotetext{
* Chemistry Institute, UNESP Araraquara-SP.
} 
isolating each quadrant using rubber dam, the coronal seal was removed and material was collected within the root canals using the method already described, to once again evaluate the microbiological conditions.

\section{Microbiological laboratory procedures}

The contaminated paper points were placed in test tubes with RTF and sent for microbiological processing. At the Microbiology laboratory, 4-6 glass beads and a sterile metal wing were added to the test tubes containing the samples. The tubes were agitated for 2 min in a Mixtron mixer (Toptronix, São Paulo, Brazil) at maximum speed. Subsequently, the samples were serially diluted up to 5-10 times in Sorensen phosphate buffer (SPB) under laminar airflow. A volume of $0.05 \mathrm{~mL}$ of the pure samples and of each dilution was plated, with a sterile calibrated pipette, onto plates containing blood agar (As), Mitis Salivarius agar (Ms; Difco, Detroit, MI, USA) and blood agar supplemented with $5.0 \mu \mathrm{g} / \mathrm{mL}$ haemin and $1.0 \mu \mathrm{g} / \mathrm{mL}$ menadione (Ask; Sigma Chemical Co., St. Louis, MO, USA).

The Ask plates were incubated anaerobically using the GasPak system for 7-10 days. The Ms and SB20 plates were incubated in microareophilic environment using the candle jar system for 2-3 days, and the Ask plates aerobically for $24-48 \mathrm{~h}$, at $37^{\circ} \mathrm{C}$. After incubation, colonies were counted using a stereomicroscope (Nikon, Yokohama, Japan) under reflected light and the $\mathrm{CFU} / \mathrm{mL}$ was determined.

To evaluate the microbiological results, the colony forming units were counted, in CFUs, for the different culture mediums. The number of colony forming units was converted into decimal logarithms and statistical comparison was done by analyzing the variance of three factors: 1) Group, 2) Microorganisms: aerobic, anaerobic and microareophilic, and 3) Time, being either before or after biomechanical preparation. This analysis was complemented by the Tukey Test and by the Student test at a 5\% significance level.

\section{RESULTS}

Figures 1 to 4 represent the values of the CFU counts relative to the four experimental groups by means of a dispersion graph. In each experimental group, the CFUs are divided into groups representing the aerobic, anaerobic and

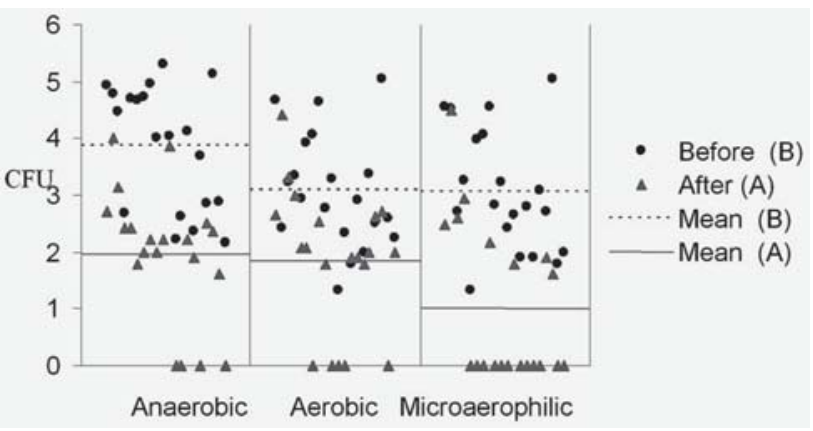

FIGURE 1- Graphic representation of microorganism count logarithms in CFUs relative to Group 1 microaerophilic environments.

In groups 1 and 2, there was a reduction in microorganisms in relation to groups 3 and 4, where there was an increase in the number of microorganisms. The analysis of variance indicated that the only significant interaction was between Group and Time.

The results indicated that "before" biomechanical preparation the groups were homogeneous as to the number of microorganisms. And "after", there were significant differences between the means (Table 2). Groups 1 (NaOCl) and 2 (CHX) presented significant $\mathrm{CFU}$ reduction, less than the mean of Groups 3 (saline solution) and 4 (no mechanical preparation).

In relation to the microorganisms, the anaerobes presented a greater mean of reduction $(\mathrm{p}<0.05)$ and the other two, aerobic and microaerophilic, presented lower means, but were not significantly different to each other $(\mathrm{p}<0.05)$.

\section{DISCUSSION}

During the biomechanical preparation of teeth with periapical lesions, the antimicrobial action of endodontic irrigants played an important role in disinfecting the root canals. A significant reduction in the number of microorganisms after biomechanical preparation with bactericidal solutions, such as sodium hypochlorite $2,4,16,18$, has been demonstrated.

The sodium hypochlorite solution, in different concentrations, is the most widely used irrigating solution ${ }^{5}$. The bactericidal action of sodium hypochlorite solution is proportional to its concentration. On the other hand, tissue irritation is higher when a concentrated solution is used ${ }^{20}$. Besides the antimicrobial activity, sodium hypochlorite solution has the capacity to dissolve organic material and detergent action, which results in good cleaning capacity when associated with EDTA ${ }^{26}$.

Chlorhexidine solution has demonstrated antimicrobial effectiveness, along with its continuing action for long periods of time $e^{10,13,24}$.

In this study, microbiological evaluation of the root canals was carried out after thirty days. This period was important to evaluate the possibility of reinfection of the root canal by microorganisms remaining within the root canal system ${ }^{2,4}$.

Since the endodontic microbiota is complex and diverse,

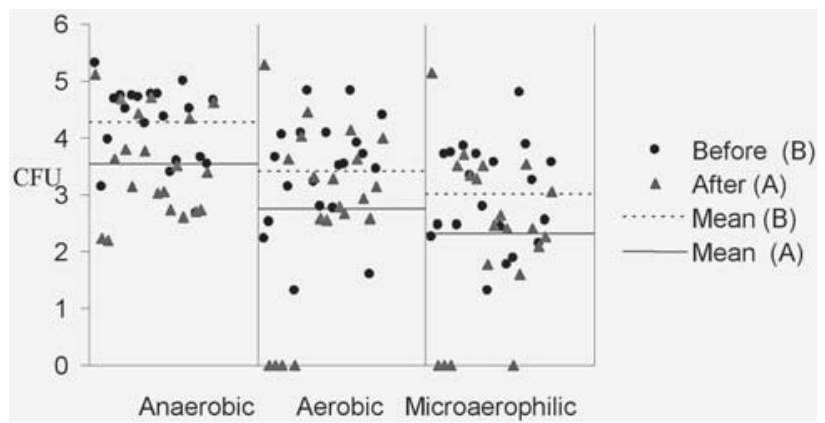

FIGURE 2- Graphic representation of microorganism count logarithms in CFUs relative to Group 2 
being predominantly anaerobic ${ }^{1,11,21}$, it was necessary to use diverse culture mediums containing different nutrients and incubated under different ambient conditions (aerobic, anaerobic and microaerophilic) to isolate the various different microorganisms from the root canal ${ }^{4,19}$.

For the canals in which saline solution was used, the mechanical action of instrumentation was not sufficient to

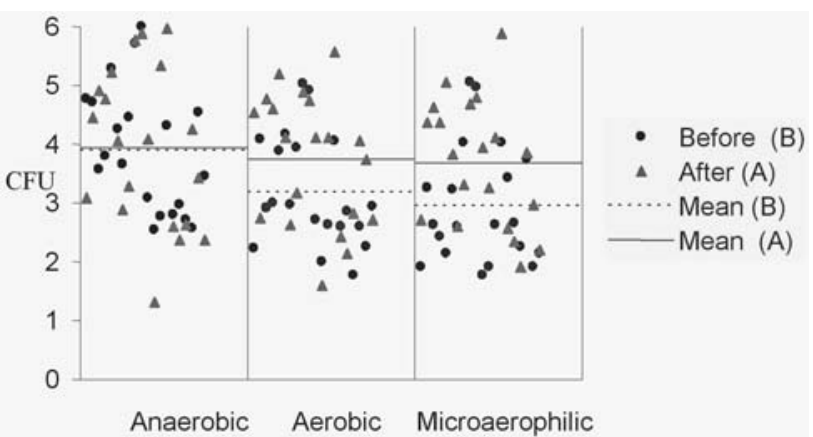

FIGURE 3- Graphic representation of microorganism count logarithms in CFUs relative to Group 3 reduce the CFUs. As such, their number had increased after a period of thirty days. A similar result was observed in the Control Group, where no mechanical preparation was undertaken.

The reduction of CFUs was only observed when biomechanical preparation was undertaken using antimicrobial irrigating solutions $(\mathrm{NaOCl}$ and $\mathrm{CHX})$. In these

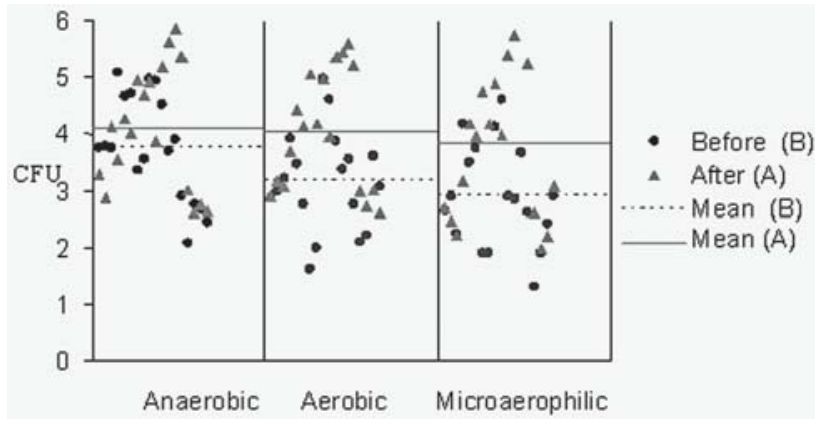

FIGURE 4- Graphic representation of microorganism count logarithms in CFUs relative to Group 4

TABLE 2- Mean and standard deviation (SD) of microorganism counts transformed into logarithms and the Student T test to compare the count means before and after application of treatment

\begin{tabular}{|c|c|c|c|c|c|c|}
\hline Group & Microorganism & Time & Mean & SD & $\mathrm{t}$ & $\mathbf{P}$ \\
\hline \multirow[t]{6}{*}{ Group 1} & Anaerobic & Before & 3.864 & 1.084 & & \\
\hline & & After & 1.969 & 1.179 & 8.076 & $<0.001$ \\
\hline & Aerobic & Before & 3.073 & 1.001 & & \\
\hline & & After & 1.840 & 1.251 & 3.946 & 0.001 \\
\hline & Microaerophilic & Before & 3.067 & 1.074 & & \\
\hline & & After & 0.998 & 1.374 & 7.626 & $<0.001$ \\
\hline \multirow[t]{6}{*}{ Group 2} & Anaerobic & Before & 4.244 & 0.700 & & \\
\hline & & After & 3.518 & 0.884 & 4.555 & $<0.001$ \\
\hline & Aerobic & Before & 3.375 & 0.953 & & \\
\hline & & After & 2.745 & 1.572 & 1.815 & 0.085 \\
\hline & Microaerophilic & Before & 2.976 & 0.888 & & \\
\hline & & After & 2.335 & 1.433 & 1.724 & 0.101 \\
\hline \multirow[t]{6}{*}{ Group 3} & Anaerobic & Before & 3.898 & 1.060 & & \\
\hline & & After & 3.936 & 1.351 & 0.148 & 0.884 \\
\hline & Aerobic & Before & 3.180 & 0.934 & & \\
\hline & & After & 3.735 & 1.125 & 2.309 & 0.032 \\
\hline & Microaerophilic & Before & 2.935 & 0.996 & & \\
\hline & & After & 3.673 & 1.089 & 3.028 & 0.007 \\
\hline \multirow[t]{6}{*}{ Group 4} & Anaerobic & Before & 3.756 & 0.928 & & \\
\hline & & After & 4.094 & 1.078 & 1.326 & 0.201 \\
\hline & Aerobic & Before & 3.165 & 0.878 & & \\
\hline & & After & 4.032 & 1.051 & 3.203 & 0.005 \\
\hline & Microaerophilic & Before & 2.908 & 0.907 & & \\
\hline & & After & 3.827 & 1.329 & 3.079 & 0.006 \\
\hline
\end{tabular}


groups, the microorganisms were detected, but in lower numbers than the canals prepared with saline solution or in the control group.

The best results obtained with the chlorhexidine solution may be associated to its residual action. Rosenthal et al. ${ }^{15}$ (2004) evaluated the residual effect or substantivity of chlorhexidine solution in root canal systems. Root canals of bovine teeth were obturated either with or without previous immersion in $2 \%$ chlorhexidine solution. The evaluation of dentin samples demonstrated that chlorhexidine provided antimicrobial effect up to twelve weeks after root canal obturation. The minor antimicrobial effect observed for sodium hypochlorite solution may be related to its lack of substantivity.

On the other hand, chlorhexidine solution presents the lowest capacity to clean the root canal walls, as demonstrated by Yamashita, et al. ${ }^{26}, 2003$, using an Scanning Electron Microscope. In this way, an alternative option could be to do the final irrigation with chlorhexidine solution and use sodium hypochlorite solution during biomechanical preparation.

Ercan, et al. ${ }^{3}$ (2004) studied the antimicrobial action of $5.25 \%$ sodium hypochlorite solution and $2 \%$ chlorhexidine in human teeth having necrotic pulp and periapical lesion, using the culture technique, and reported a significant reduction in the microbiota for both irrigation solutions tested.

The partial action of biomechanical preparation to disinfect the root canal, even with the use of bactericidal solutions, suggests that the role of intracanal dressing is fundamental in the endodontic treatment of teeth with periapical lesions. Holland, et al. ${ }^{6}$ (1992) studied the influence of irrigation and intracanal dressing on the healing process of dogs' teeth with apical periodontitis and observed that the intracanal dressing was more important for success than the type of irrigating solution used (saline solution or $0.5 \%$ $\mathrm{NaOCl}$ at $0.5 \%)$. The employment of hydroxide-based intracanal dressing in the endodontic treatment of teeth with periapical lesions is important to deactivate the effects of endotoxins released by gram-negative microorganisms, since the irrigating solutions do not have this capacity ${ }^{22}$.

Tanomaru Filho, et al. ${ }^{23}$ (2002) studied the influence of $\mathrm{NaOCl}$ and $\mathrm{CHX}$ irrigating solutions and the use of calcium hydroxide-based intracanal dressing for periapical repair after endodontic treatment of teeth with periapical lesions in dogs. The root canals irrigated with sodium hypochlorite or chlorhexidine solution were obturated in a single visit or after the use of an intracanal dressing with a calcium hydroxide paste. The results demonstrated that utilization of the intracanal dressing was more important for periapical repair than the irrigating solution used.

It can be concluded that the use of antimicrobial irrigating solutions during biomechanical preparation promotes the reduction of endodontic microbiota. However, a considerable number of microorganisms were still observed.

\section{ACKNOLEDGEMENTS}

\author{
FAPESP - financial support \# 02/06656-0
}

\section{REFERENCES}

1- Ando N, Hoshino E. Predominant obligate anaerobes invading the deep layers of root canal dentine. Int Endod J. 1990;23:20-7.

2- Byström A, Sundqvist G. The antibacterial action of sodium hypochlorite and EDTA in 60 cases of endodontic therapy. Int Endod J. 1985;18:35-40.

3- Ercan E, Ozekinci T, Atakul F, Gul K. Antibacterial activity of 2\% chlorhexidine gluconate and $5.25 \%$ sodium hypochlorite in infected root canal: in vivo study. J Endod. 2004;30:84-7.

4- Gomes BPFA, Lilley JD, Drucker DB. Variations in the susceptibilities of components of the endodontic microflora to biomechanical procedures. Int Endod J. 1996;29:235-41.

5- Haumann CHJ, Love RM. Biocompatibility of dental materials used in contemporary endodontic therapy: a review. Part 1. Intracanal drugs substances. Int Endod J. 2003;36:75-85.

6- Holland R, Soares IJ, Soares IM. Influence of irrigation and intracanal dressing on the healing process of dogs' teeth with apical periodontitis. Endod Dent Traumatol. 1992;8:223-9.

7- Leonardo MR. Preparo biomecânico dos canais rootes. In: Leonardo MR, Leal JM. Endodontia: Tratamento dos canais rootes. 3 ed. São Paulo: Ed. Médica Panamericana; 1998:359-66.

8- Leonardo MR, Almeida WA, Ito IY, Silva LAB. Radiographic and microbiologic evaluation of post treatment apical and periapical repair of root canals of dog's teeth with experimentally induced chronic lesion. Oral Surg Oral Med Oral Pathol. 1994;78:232-8.

9- Leonardo MR, Rossi M A, Silva LAB, Ito IY, Bonifácio KC. SEM evaluation of bacteria biofilm and microorganisms on the apical external root surface of human teeth. J Endod. 2002;28:815-8.

10- Leonardo MR, Tanomaru Filho M, Silva LAB, Nelson Filho P, Bonifácio KC, Ito IY. In vitro antimicrobial activity of $2 \%$ chlorhexidine used as a root canal irrigant solution. J Endod. 1999;25:167-71.

11- Molander A, Reit C, Dahlén G, Kvist T. Microbiological status of root-filled teeth with apical periodontitis. Int Endod J. 1998;31:1-7.

12- Nair PN, Henry S, Cano V, Vera J. Microbial status of apical root canal system of human mandibular first molars with primary apical periodontitis after "one-visit” endodontic treatment. Oral Surg Oral Med Oral Pathol Oral Radiol Endod. 2005;99:231-52.

13- Ohara P, Torabinejad M, Kettering JD. Antibacterial effects of various endodontic irrigants on selected anaerobic bacteria. Endod Dent Traumatol. 1993;9:95-100.

14- Peters OA, Schönenberg K, Laib A. Effects of four Ni-Ti preparation techniques on root canal geometry assessed by micro computed tomography. Int Endod J. 2001;34:221-30.

15- Rosenthal S, Spangberg L, Safavi K. Chlorhexidine substantivity in root canal dentin. Oral Surg Oral Med Oral Pathol Oral Radiol Endod. 2005;98:488-92.

16- Shuping GB, Orstavik D, Sigurdsson A, Trope M. Reduction of intracanal bacteria using nickel-titanium rotary instrumentation and various medications. J Endod. 2000;26:751-5. 
17- Silva L, Nelson-Filho P, Leonardo MR, Rossi MA, Pansani CA. Effect of calcium hydroxide on bacterial endotoxin in vivo, J Endod. 2002;28:94-8.

18- Siqueira JR JF, Rocas IN, Favieri A, Lima KC. Chemomechanical reduction of the bacterial population in the root canal after instrumentation and irrigation with $1 \%, 2.5 \%$, and $5.25 \%$ sodium hypochlorite. J Endod. 2000;26:331-4.

19- Soares JA, Leonardo MR, Tanomaru Filho M, Silva LAB, ITO IY. Effect of biomechanical preparation and calcium hydroxide pastes on the anti-sepsis of root canal systems in dogs. J Appl Oral Sci. 2005;12:110-7.

20- Spangberg L, Engestrom B, Langeland K. Biologic effects of dental material. III. Toxicity and antimicrobial effects of endodontic antiseptics in vitro. Oral Surg Oral Med Oral Pathol. 1973;36:85671.

21- Sundqvist G, Figdor D, Persson S, Sjögren U. Microbiologic analysis of teeth with failed endodontic treatment and the outcome conservative treatment. Oral Surg Oral Med Oral Pathol. 1998;85:8693.

22- Tanomaru JMG, Leonardo MR, Tanomaru Filho M, Bonetti Filho I, Silva LAB. Effect of different irrigation solutions and calcium hydroxide on bacterial LPS. Int Endod J. 2003;36:733-9.

23- Tanomaru Filho M, Leonardo MR, Silva LA. Effect of irrigating solution and calcium hydroxide root canal dressing on the repair of apical and periapical tissues of teeth with periapical lesion. J Endod. 2002;28:295-9

24- Weber CD, McClanaham SB, Miller GA, Diener-West M, Johnson JD. The effect of passive ultrasonic activation of $2 \%$ chlorhexidine or $5.25 \%$ sodium hypochlorite irrigant on residual antimicrobial activity on root canal. J Endod. 2003;29:562-4

25- Wu MK, Van Der Sluis LWM, Wesselink PR. The capability of two hand instrumentation techniques to remove the inner layer of dentine in oval canals. Int Endod J. 2003;36:218-24.

26- Yamashita JC, Tanomaru Filho M, Leonardo MR, Rossi MA, Silva LAB. Scanning electron microscopic study of the cleaning ability of chlorhexidine as a root-canal irrigant. Int Endod J. 2003;36:391-4 